\title{
Experimental Study on Mechanical Properties of Pervious Concrete Containing Recycled Aggregate
}

\author{
Abdulfattah A. Amin ${ }^{1}$, Khaleel H. Younis ${ }^{1,2, *}$, Firas F. Jirjees ${ }^{1}$, Talib K. Ibrahim ${ }^{3}$ \\ ${ }^{1}$ Department of Road Construction, Erbil Technology College, Erbil Polytechnic University, Erbil, Iraq \\ ${ }^{2}$ Department of Civil Engineering, Engineering College, Tishk International University, Erbil, Iraq \\ ${ }^{3}$ Department of Environmental Engineering, Engineering College, Knowledge University, Erbil, Iraq
}

Received June 23, 2021; Revised July 27, 2021; Accepted August 27, 2021

\section{Cite This Paper in the following Citation Styles}

(a): [1] Abdulfattah A. Amin, Khaleel H. Younis, Firas F. Jirjees, Talib K. Ibrahim, "Experimental Study on Mechanical Properties of Pervious Concrete Containing Recycled Aggregate," Civil Engineering and Architecture, Vol. 9, No. 6, pp. 1735-1743, 2021. DOI: 10.13189/cea.2021.090607.

(b): Abdulfattah A. Amin, Khaleel H. Younis, Firas F. Jirjees, Talib K. Ibrahim (2021). Experimental Study on Mechanical Properties of Pervious Concrete Containing Recycled Aggregate. Civil Engineering and Architecture, 9(6), 1735-1743. DOI: 10.13189/cea.2021.090607.

Copyright $(2021$ by authors, all rights reserved. Authors agree that this article remains permanently open access under the terms of the Creative Commons Attribution License 4.0 International License

\begin{abstract}
This investigational study aims to examine the influence of using recycled coarse aggregate (RCA) instead of natural coarse aggregate (NCA) on the fresh properties (workability) and mechanical properties of pervious concrete (PC). The mechanical properties include compressive strength, splitting tensile strength and flexural strength and the impact resistance of PC was also assessed using drop weight test. In total, four mixes were prepared (including control mix with $100 \% \mathrm{NCA}$ ) in which various ratios of RCA $(30 \%, 70 \%$ and $100 \%)$ replaced the NCA in the preparation of $\mathrm{PC}$ mixes without using any fine aggregate and fixing the water-cement ratio $(\mathrm{w} / \mathrm{c})$ to 0.4 . The outcomes of the study reveal that the content of the RCA has significant adverse effects on the workability and mechanical performance of the investigated mixtures. This adverse effects increase with the increase of the content of RCA. The strength reduction, compared to the mix with NCA, reached to $59 \%$ for compressive, $28 \%$ of the splitting tensile, $38 \%$ for flexural strength and $50 \%$ for the impact resistance when $100 \%$ RCA is used.
\end{abstract}

Keywords Pervious Concrete, Recycled Aggregate, Waste Construction Materials, Compressive Strength, Tensile Strength, Flexural Strength, Impact Resistance, Slump test, Drop Weight Test

\section{Introduction}

The amassing of massive quantities of waste materials in particular waste of construction and demolition activities, especially in urban areas, is one of the world's largest sustainability issues and environmental concerns. If such a large amount of waste is disposed of, the planet will face major environmental issues, such as the depletion of landfill space. Another question of sustainability is the depletion of natural resources for aggregates used in concrete manufacturing [1-3].

Following rapid industrial growth, the area of buildings and roads has grown, reducing the permeable area of surface runoff during heavy rains. As a result, rainwater that previously evaporated or drained into the groundwater is either flowing into the stream through the drainage system or accumulating on the road's surface. As a result, city flooding is increasing, groundwater levels are dropping due to reduced rainwater surface penetration, and environmental issues such as the heat island phenomenon in urban areas are emerging [4].

Pervious concrete (PC) is a form of concrete with a special structure characterized with a large content of voids (high porosity), usually between 15 and 35 percent by volume and interconnected pore structure [5].

Owing to the highly interconnected void structures, PC allows water to freely pass through its pores. This helps in decreasing flooding risk, recharging ground water, reducing storm water runoff, as well as diminishing noise 
due to vehicle tires contact with road's surface. Furthermore, $\mathrm{PC}$ is developed at a low cost, making it one of the most promising sustainable systems for urban drainage. However, it needs regular maintenance to avoid sediment and vegetation which hinder the movement of water and affecting its high permeability. It may also have durability issues due to abrasion and freeze/thaw cycles. PC contains little to no fine aggregate, despite the fact that its constituent materials are identical to those of regular concrete that is why it is also called no-fines concrete. Low-traffic pavements including parking lots and sidewalks, as well as around homes, highway shoulders, and medians are the main applications of PC [6].

In an experimental study the results showed that the use of recycled coarse aggregate (RCA) decreases the workability (slump) of concrete because of recycled aggregate's high water absorption and rough surface. Similarly, the strengths values of normal concrete including compressive, splitting tensile and flexural decreased by $24.3 \%, 10.7 \%$ and $3.2 \%$ respectively, when RCA was used. This decrease can be attributed to the weakness of the recycled aggregate $[1,7]$.

On one hand, it has been found that PC shows lower strength than traditional concrete and the reduction depends on the strength grade of the concrete, as reported by [8]. In this study it was reported that the compressive strength reduced by $18.2 \%$ for M15, $14.5 \%$ for M20 and $12.6 \%$ for M25. Same study showed tensile strength reduction of $40.2 \%, 38.4 \%$ and $36.2 \%$ for M15, M20 and M25 grades respectively, and reductions of $29.9 \%, 27.6 \%$ and $24.6 \%$ for the flexural strength when compared to the normal concrete [8].

On the other hand, it was observed that replacing natural aggregate with recycled aggregate resulted in a significant increase in permeability coefficient while adversely affecting the mechanical properties of PC to some extent. It has also been reported that partially replacing cement with cementitious materials such as fly ash, silica fume, rice husk ash, cement kiln dust, and furnace slag will improve pervious concrete's compressive strength and permeability. It is also concluded that incorporating waste materials into pervious concrete would significantly reduce the impact of concrete on the environmental and enhances the sustainability of concrete [9].

Furthermore, it has been experimentally found, using drop weight test, that adding steel fibers to the concrete mixes with $1.25 \%$ by volume of concrete improves the impact resistance of concrete compared to that of plain concrete [10].

In Iraq, there are very few studies on the efficiency of PC with recycled aggregate in terms of mechanical properties and behavior under impact loads.

As a result, the effect of replacing NCA with various ratios of RCA on the workability, mechanical properties, and impact resistance of $\mathrm{PC}$ is investigated in this paper. The experimental work, findings, and conclusions are presented in the following sections.

\section{Experimental Program}

\subsection{Materials}

The current study used Portland cement type CEM I, which satisfies BS EN 197 requirements. Table 1 shows the cement's chemical analysis (as given by the supplier).

Fine aggregate was completely left out in the mixes to create large open textured porous concrete. The coarse aggregate employed in this study were natural and recycled and are shown in (Figure 1).

The first one was natural rounded river aggregate. The second was recycled aggregate, which came from old concrete remnants left over from the demolition of old concrete structures. The natural and recycled coarse aggregates had the same maximum size of $12.5 \mathrm{~mm}$ in which $70 \%$ of this size was used, while the remaining $30 \%$ of the coarse aggregate was from those passing sieve $9.5 \mathrm{~mm}$ and remaining on sieve $4.5 \mathrm{~mm}$. Table 2 lists the properties of coarse aggregates used in this study.

Table 1. Chemical composition of the Portland cement (CEM I)

\begin{tabular}{ccccccccc}
\hline $\mathbf{S i O}_{2}$ & $\mathbf{A l}_{2} \mathbf{O}_{3}$ & $\mathbf{F e}_{2} \mathbf{O}_{3}$ & $\mathbf{C a O}$ & $\mathbf{M g O}$ & $\mathbf{S O}_{3}$ & $\mathbf{N a}_{2} \mathbf{O}$ & $\mathbf{K}_{2} \mathbf{O}$ & $\mathrm{Na}_{2} \mathrm{O}$ \\
\hline 20.94 & 4.96 & 2.92 & 65.9 & 0.78 & 2.8 & 0.25 & 0.42 & 0.52 \\
\hline
\end{tabular}

Table 2. Physical properties of Coarse Aggregates (CA)

\begin{tabular}{|c|c|c|}
\hline \multirow{2}{*}{ Property } & \multicolumn{2}{|c|}{ Type of Aggregate } \\
\hline & NCA & RCA \\
\hline Shape & Rounded & Angular \\
\hline Surface texture & Smooth & Rough \\
\hline Specific gravity of the Saturated Surface Dry (SSD) condition & 2.62 & 2.47 \\
\hline
\end{tabular}




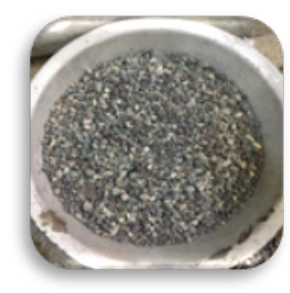

(a)

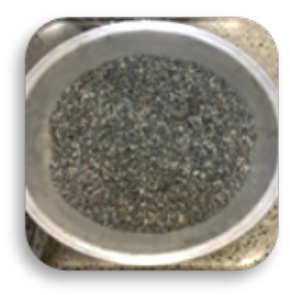

(b)

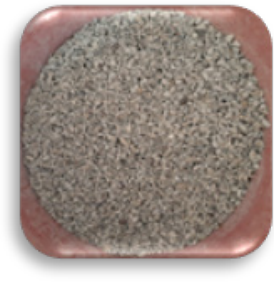

(c)

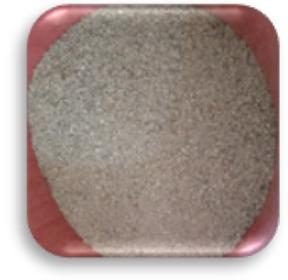

(d)

Figure 1. Coarse aggregate according to sieve size (passing): (a) Natural 12.5mm, (b) Natural 9.5mm, (c) Recycled 12.5mm, (d) Recycled 9.5mm

Table 3. Mix proportions $\left(\mathrm{kg} / \mathrm{m}^{3}\right)$ and code of mixes of current study

\begin{tabular}{cccccccc}
\hline Mix No. & Mix code & $\begin{array}{c}\text { Air } \\
\text { content } \%\end{array}$ & Cement & Water & $\begin{array}{c}\text { Fine Agg. } \\
\text { (FA) }\end{array}$ & $\begin{array}{c}\text { Coarse Agg. } \\
\text { (NCA) }\end{array}$ & $\begin{array}{c}\text { Coarse Agg. } \\
\text { (RCA) }\end{array}$ \\
\hline M1 & PCN100 & 17 & 400 & 160 & 0 & 1423 & 0 \\
M2 & PCR30 & 17 & 400 & 160 & 0 & 996 & 402 \\
M3 & PCR70 & 17 & 400 & 160 & 0 & 427 & 939 \\
M4 & PCR100 & 17 & 400 & 160 & 0 & 0 & 1342 \\
\hline
\end{tabular}

Table 4. Details PC samples prepared for each mix in this study

\begin{tabular}{cccc}
\hline Sample Type & Sample Size $(\mathbf{m m})$ & Number of Samples & Associated Test \\
\hline Cubes & 100 & 3 & Compressive strength \\
Cylinders & $100 \times 200$ & 3 & Splitting Tensile strength \\
Prisms & $100 \times 100 \times 400$ & 3 & Flexural strength \\
Cylindrical discs & 152.4 dia., 63.5 hgt. & 3 & Impact resistance \\
\hline
\end{tabular}

\subsection{Experimental Work}
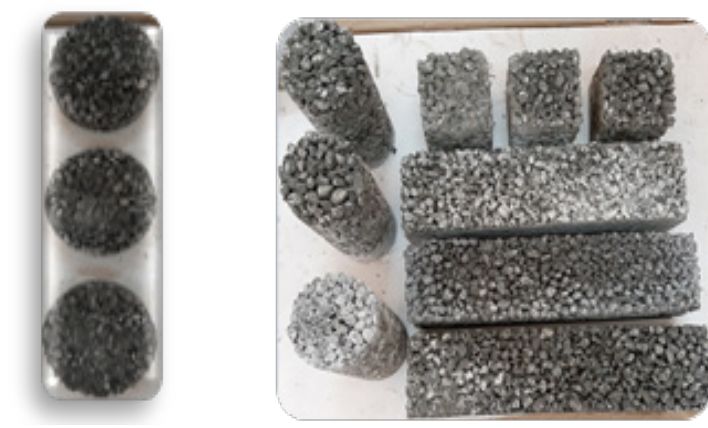

Figure 2. Some PC samples prepared in this study

In total, four mixes were prepared and tested in the study. Table 3 lists the study variables, code of mixes and mix proportions. The aggregate used was in a saturated surface dry (SSD) condition, and same water/cement (w/c) ratio of (0.4) was used for all mixes. To prepare the concrete mixtures, a $0.08 \mathrm{~m}^{3}$ capacity pan mixer was employed to mix the constituents of the concrete. The type, size and number of the PC samples prepared for each mix are shown in Table 4. When designing the concrete mixes, the physical properties of NCA and RCA were taken into account especially the difference in specific gravity at saturated surface dry condition. The blended coarse aggregates' values were estimated by assuming that the properties of NCA and RCA influence the blended coarse aggregate proportionally. After casting, the concrete specimens were protected using plastic sheets and then left to cure for 24 hours before demoulding. Afterword, the samples were moved to water tanks for the curing process for 28 days. Figure 2 shows some of the various PC samples prepared in this study.

\subsection{Experiments}

\subsubsection{Workability "Slump Test"}

Slump tests were used to evaluate the fresh concrete properties (workability) of all mixes according to the standard BS EN 12350-2 [11] as shown in (Figure 3).
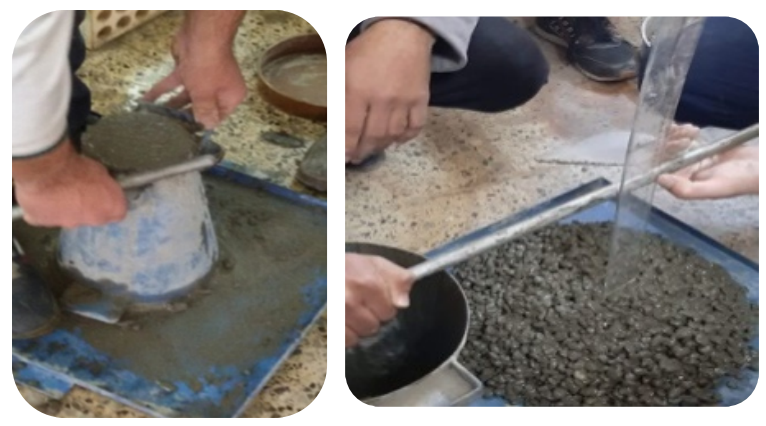

Figure 3. Slump test

\subsubsection{Compressive Strength Test}

The $100 \mathrm{~mm}$ cubes specimens were examined for 
compression after 28 days of curing using the BS EN 12390-3 [12] standard procedure. The compressive strength test machine is shown in (Figure 4).
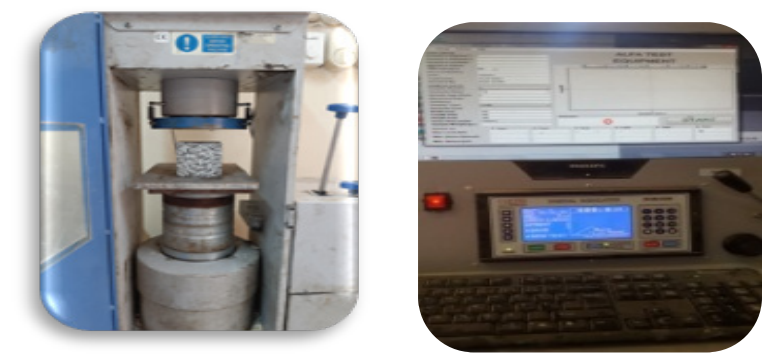

Figure 4. Compressive strength test machine

\subsubsection{Splitting Tensile Strength Test}

This test was conducted using the BS EN 12390-6 [13] standard procedure and $100 \times 200 \mathrm{~mm}$ cylinders specimens. The splitting tensile strength test machine is shown in (Figure $5)$.

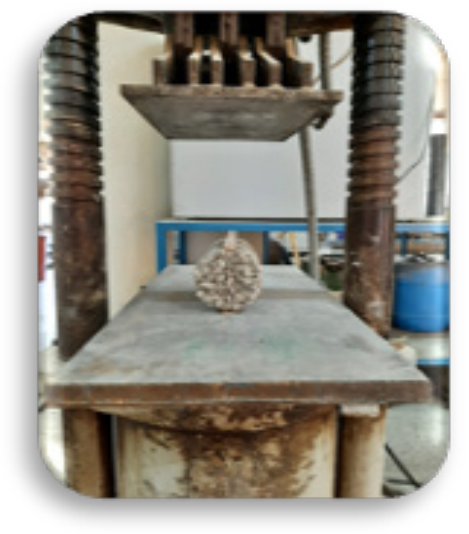

Figure 5. Machine for splitting tensile strength test

\subsubsection{Flexural Strength Test}

The concrete specimens were assessed for its flexural strength after 28 days of curing according to the standard procedure of BS EN 12390-6 [14]. The $(100 \times 100 \times 400)$ $\mathrm{mm}$ prisms were tested in two-point loading over a length of $300 \mathrm{~mm}$ using the flexural strength test machine as shown in (Figure 6).

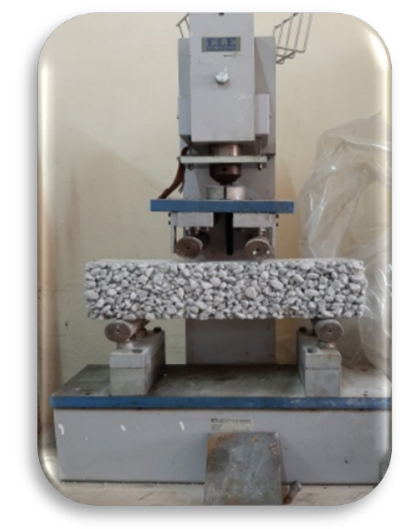

Figure 6. Flexural strength test machine during testing

\subsubsection{Impact Resistance Test}

As per the ACI 544.2R-89 [15] standard test, the concrete discs were assessed for impact resistance at the age of 28 days. The impact load was applied repeatedly in the form of blows using a $10 \mathrm{lb}(4.54 \mathrm{~kg})$ compaction hammer that was dropped from an 18-in. (457-mm) height on a steel ball with a diameter of $63.5 \mathrm{~mm}$ that was mounted in the middle of the top surface of the concrete disc. The number of blows (N1) and (N2) that resulted in the first visible crack and specimen failure were reported. Figure 7 describes how the impact load was applied in this study to assess concrete's impact resistance.
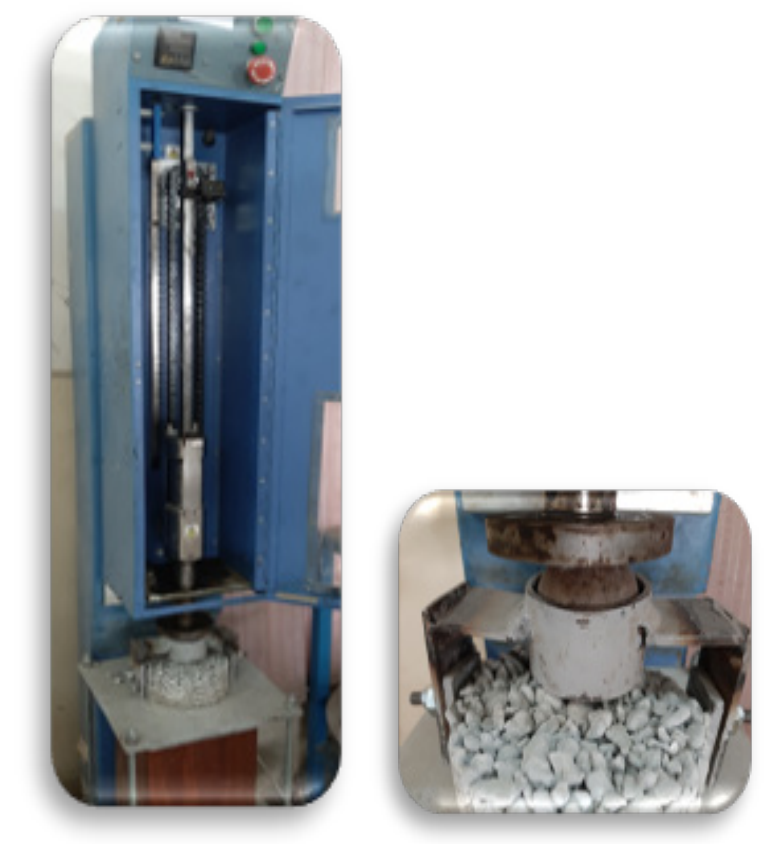

Figure 7. Concrete impact resistance testing

Impact resistance energy was calculated for all specimens using (1), $[16,17]$

$$
\text { Impact energy }(\mathrm{IE})=\mathrm{N} \times \mathrm{g} \times \mathrm{m} \times \mathrm{h}
$$

Where:

IE = Impact energy (resistance) (N.m),

$\mathrm{N}=$ Number of blows,

$\mathrm{g}$ : Acceleration of Gravity $=9.81 \mathrm{~m} / \mathrm{s}^{2}$

$\mathrm{m}$ : Mass of hummer $\mathrm{kg}=4.57 \mathrm{~kg}$, and

h: Height of drop hummer $=0.457 \mathrm{~m}$.

\subsection{Results and Discussion}

\subsubsection{Workability of concrete "Slump Test"}

The slump test method was used to evaluate the workability of all mixture. Table 5 and Figure 8 display the slump test results in millimeters for all mixes. The table also highlights the differences in slump between M1 and other mixes. 
Table 5. Results of slump test values (+ increase or - decrease) compared to M1

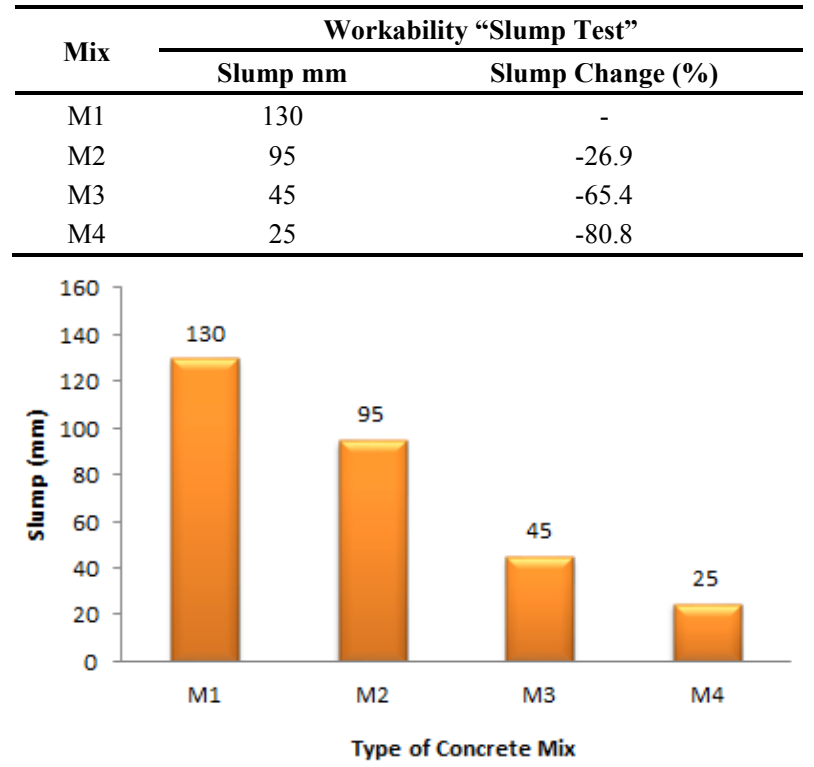

Figure 8. The effect of using RCA instead of NCA on the slump value of PC

The results in (Figure 8) show that replacing NCA with RCA in PC mixes decreases slump values. Increased NCA replacement with RCA resulted in a direct reduction in workability. As 30 percent, 70 percent, and 100 percent of NCA is replaced with RCA in PC mixes, the workability of the concrete is reduced by around $27 \%, 65 \%$, and $81 \%$, respectively, as compared to M1. This may be attributed to the rough surface texture of RCA and its higher water absorption than NCA [1, 18-20].

\subsubsection{Compressive Strength}

Table 6 and Figure 9 demonstrate the 28-day compressive strength values of all mixes. Those values represent the average of 3 specimens. The table also highlights the differences in strength between M1 and other mixes.

Table 6. Compressive strength test values (+ increase or - decrease) compared to M1

\begin{tabular}{ccc}
\hline \multirow{2}{*}{ Mix } & \multicolumn{2}{c}{ Compressive strength } \\
\cline { 2 - 3 } & Strength MPa & Strength Change (\%) \\
\hline M1 & 24.6 & - \\
M2 & 15.0 & -38.9 \\
M3 & 11.4 & -53.8 \\
M4 & 10.1 & -59.0 \\
\hline
\end{tabular}

The results indicate that replacing NCA with RCA in PC mixes decreases concrete compressive strength, and that the reduction increases as the amount of NCA replaced with RCA increases. When $30 \%, 70 \%$, or $100 \%$ of NCA is replaced with RCA in PC mixes, the compressive strength of concrete is reduced by about $39 \%$, $54 \%$, and $59 \%$, respectively, when compared to M1. This reduction is predicted since the quality of RCA is low compared to that of NCA. This can be attributed to the mortar attached to the RCA's surface, which has a low density and high porosity, resulting in a weaker concrete $[1,18,20]$.

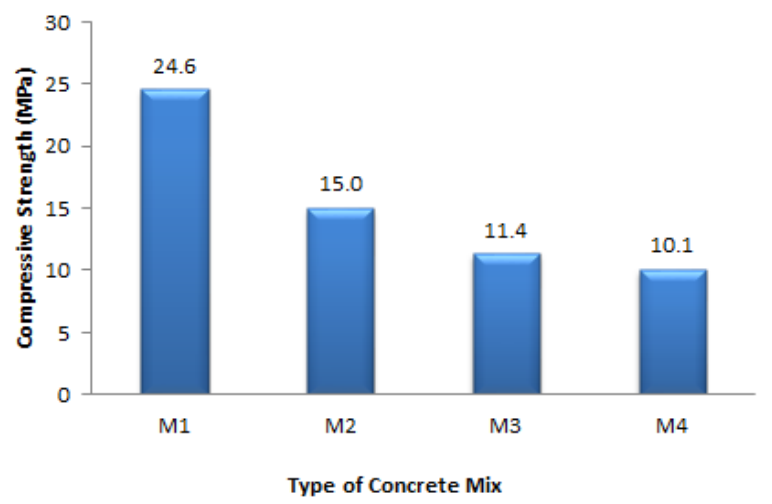

Figure 9. The effect of replacing NCA with RCA in the compressive strength value of $\mathrm{PC}$

\subsubsection{Splitting Tensile Strength}

Table 7 and Figure 10 demonstrate the 28-day splitting tensile strength values of all mixes. Those values represent the average of 3 specimens. The table also highlights the differences in strength between M1 and other mixes.

Table 7. Splitting tensile strength test values (+ increase or - decrease) compared to M1

\begin{tabular}{ccc}
\hline \multirow{2}{*}{ Mix } & \multicolumn{2}{c}{ Splitting tensile strength } \\
\cline { 2 - 3 } & Strength MPa & Strength Change (\%) \\
\hline M1 & 2.39 & - \\
M2 & 1.82 & -23.9 \\
M3 & 1.81 & -24.3 \\
M4 & 1.73 & -27.6 \\
\hline
\end{tabular}

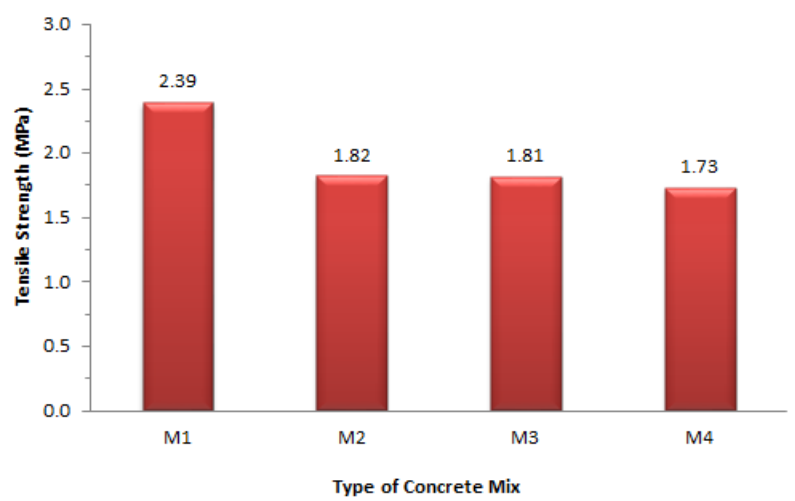

Figure 10. The effect of replacing NCA with RCA in the splitting tensile strength value of $\mathrm{PC}$

The values for splitting tensile strength follow a pattern close to that of compressive strength. When $30 \%, 70 \%$, and $100 \%$ of NCA is substituted with RCA, the strength of the PC mixes drops by about $23 \%, 24 \%$, and $28 \%$, respectively, when compared to M1. The increase in concrete porosity and the decrease in the bond between 
the aggregate and the matrix are responsible for the drop in the splitting tensile strength values of PC with RCA [20, 21].

\subsubsection{Flexural Strength}

Table 8 and Figure 11 demonstrate the 28-day flexural strength values of all mixes. Those values represent the average of 3 specimens. The table also highlights the differences in strength between M1 and other mixes.

Table 8. Flexural strength test values (+ increase or - decrease) compared to M1

\begin{tabular}{ccc}
\hline \multirow{2}{*}{ Mix } & \multicolumn{2}{c}{ Flexural strength } \\
\cline { 2 - 3 } & Strength MPa & Strength Change (\%) \\
\hline M1 & 2.63 & - \\
M2 & 1.99 & -24.3 \\
M3 & 1.69 & -35.7 \\
M4 & 1.63 & -38.0 \\
\hline
\end{tabular}

The values for flexural strength follow a pattern close to that of compressive strength and splitting tensile strength. The flexural strength of M1 is $2.63 \mathrm{MPa}$. In M2 where only $30 \%$ of natural aggregate replaced with recycled aggregate, the results showed lower strength than that of M1 by $24 \%$. Furthermore, in M3 and M4 where $70 \%$ and $100 \%$ of natural aggregate replaced with recycled aggregate, the results showed lower strength than that of the M1 by $36 \%$ and $38 \%$, respectively. The mortar adhered to the recycled aggregate surface causes the flexural strength of PC with RCA to decrease, resulting in a low-density, low-strength concrete [1,20,22].

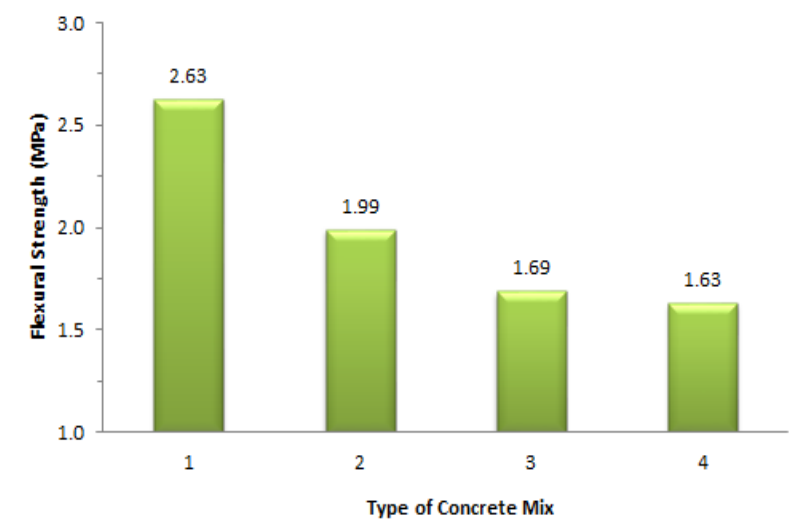

Figure 11. The effect of replacing NCA with RCA in the flexural strength value of $\mathrm{PC}$

\subsubsection{Impact Resistance}

Table 9 shows the number of blows (average of 3 disc samples) that caused initial and failure cracks of the 28 days impact resistance test of PC discs for all mixes, it also shows the percentage of reduction in the impact resistance of PC compared M1 where natural aggregate is replaced with recycled aggregate in various ratios for mixes (M2, M3 \& M4), while Table 10 presents statistical analysis for the results.

Table 9. Results of impact resistance of the PC

\begin{tabular}{|cccc|c|c|c|c|}
\hline \multirow{2}{*}{ Mix } & \multicolumn{3}{|c|}{ No. of blows that cause: } & \multicolumn{4}{c|}{ Impact Resistance } \\
\cline { 2 - 9 } & $\begin{array}{c}\text { first crack } \\
\text { N1 }\end{array}$ & $\begin{array}{c}\text { failure } \\
\text { N2 }\end{array}$ & $\begin{array}{c}\text { Difference } \\
\text { (blows) }\end{array}$ & $\begin{array}{c}\text { First Crack } \\
\text { IE1 (N.m) }\end{array}$ & $\begin{array}{c}\text { Decrease } \\
\text { (\%) }\end{array}$ & $\begin{array}{c}\text { Ultimate Failure } \\
\text { IE2 (N.m) }\end{array}$ & $\begin{array}{c}\text { Decrease } \\
\text { (\%) }\end{array}$ \\
\hline M1 & 44 & 48 & 4 & 901 & - & 983 & - \\
M2 & 30 & 35 & 5 & 615 & 32 & 717 & 27 \\
M3 & 27 & 33 & 6 & 553 & 39 & 676 & 31 \\
M4 & 18 & 24 & 6 & 369 & 59 & 492 & 50 \\
\hline
\end{tabular}

Table 10. Statistical analysis of test results of the PC mixes.

\begin{tabular}{ccccc}
\hline \multirow{2}{*}{ Item } & \multicolumn{3}{c}{$\mathbf{N 1 / N 2}$} \\
\cline { 2 - 5 } & M1 & M2 & M3 & M4 \\
\hline Average & $44 / 48$ & $30 / 35$ & $27 / 33$ & $18 / 24$ \\
Standard Deviation & $4.58 / 4$ & $2.65 / 1.73$ & $1.73 / 3$ & $1.73 / 2.65$ \\
Coefficient of Variance & $10.41 / 8.33$ & $8.82 / 4.95$ & $6.42 / 9.09$ & $9.62 / 11.02$ \\
\hline
\end{tabular}



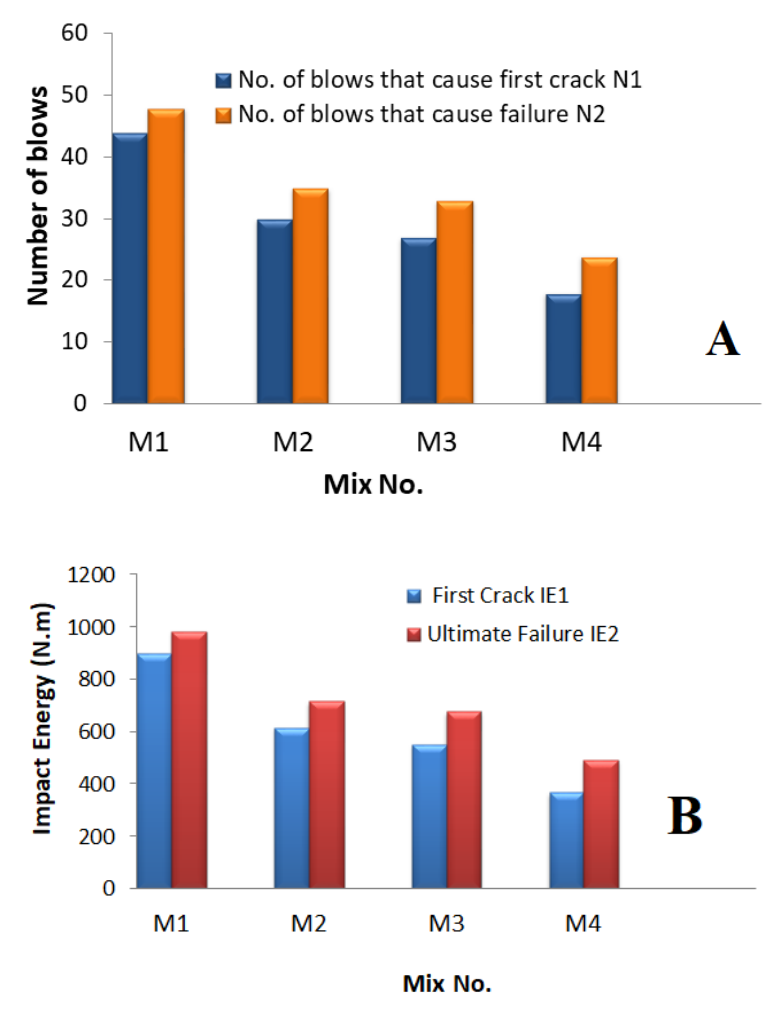

Figure 12. Impact test results of PC: (A) Number of blows, (B) Impact energy.

Figure 12 (A) and (B) show a comparison between number of blows and impact energy that cause first crack and failure in PC discs for all mixes. The general trend of the impact load resistance of the mixes with recycled aggregate shows a substantial decrease reaches more than $50 \%$ when $100 \%$ of NCA substituted with RCA as illustrated in Figure 12 (A). The reference mix M1 had an impact resistance of 901 N.m, and replacing $30 \%$ of NCA with RCA in $\mathrm{M} 2,70 \%$ in $\mathrm{M} 3$, and $100 \%$ in $\mathrm{M} 4$ resulted in a reduction in the number of blows required to cause the initial crack and those cause failure; hence, decreasing the impact resistance of the concrete as it is directly related to the number of blows. The percentages of the decrease in the impact resistance (at failure) due to the use of RCA for mixes M2, M3 and M4 are found to be $27 \%, 31 \%$ and $50 \%$, respectively, as shown in Table 9. This decline in impact resistance may be attributed to a general decrease in PC strength as aggregate size increases and how it fits together in the hardened concrete mix, as well as the fact that the overall strength of the concrete is inversely proportional to the amount of voids. Also, from another point of view, it is predicted that the adhered mortar layer of the RCA is weaker than NCA and it causes a weak link in PC mass and results in crack's propagation [17, 23, 24].

\subsubsection{Failure Pattern}

Figure 13 shows the failure patterns of PC discs with different percentages of NCA replaced with RCA in mixes
M2, M3, and M4 at 28 days' age. Since no other material, such as waste rubber tires, is applied to concrete to improve its brittleness properties, brittleness failure is obvious on those mixes [17].

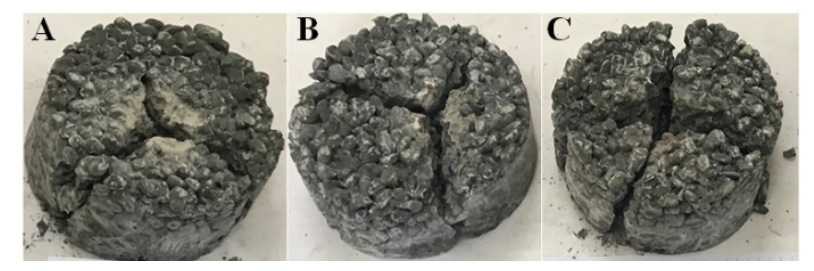

Figure 13. Failure patterns of the PC results from impact load with (A) $30 \%$, (B) $70 \%$ and (C) $100 \%$ NCA replaced with RCA

\section{Conclusions}

\section{The following can be deduced from the experimental tests findings:}

- The workability (slump values) of the mixes with RCA decreased by $27 \%, 65 \%$ and $81 \%$, respectively, for the mixes M2, M3 and M4 compared to the reference M1.

- Replacing NCA by RCA in the pervious concrete mixes caused a significant drop in the compressive strength of concrete by about $39 \%, 54 \%$ and $59 \%$, respectively, for the mixes M2, M3 and M4 compared to the reference M1.

- Replacing NCA by RCA in the pervious concrete mixes caused a significant drop in the splitting tensile strength of concrete by about $23 \%, 24 \%$ and $28 \%$, respectively, for the mixes M2, M3 and M4 compared to the reference M1.

- Replacing NCA by RCA in the pervious concrete mixes caused a significant drop in the flexural strength of concrete by about $24 \%, 36 \%$ and $38 \%$, respectively, for the mixes M2, M3 and M4 compared to the reference M1.

- Replacing NCA by RCA in the pervious concrete mixes inversely affects the impact resistance by about $27 \%, 31 \%$ and $50 \%$, respectively, for the mixes M2, M3 and M4 compared to the reference M1.

- This major reduction in pervious concrete overall strength arises from replacing NCA by RCA may highlight a significant point about the possibility of using such concrete in several applications and this may be enhanced by the addition of several materials to balance this reduction and keeping low cost of construction and ensure concrete sustainability.

\section{Acknowledgments}

We are very grateful for Erbil Polytechnic University for their appropriate and constructive support and help. 


\section{REFERENCES}

[1] Khaleel H. Younis, Firas F. Jirjees, Ganjeena Khoshnaw, Barham Haidar Ali, "Experimental Study on Performance of Recycled Aggregate Concrete: Effect of Reactive Mineral Admixtures," International Journal of Civil Engineering and Technology, vol. 10, no. 1, pp. 2566-2576, 2019. https://iaeme.com/Home/article_id/IJCIET_10_01_2 29

[2] Khaleel H. Younis, Abdulfattah A. Amin, Hemin G. Ahmed, Shelan M. Maruf, "Recycled Aggregate Concrete including Various Contents of Metakaolin: Mechanical Behavior," Advances in Materials Science and Engineering, vol. 2020, pp. Article ID 8829713, 17 pages, 2020. https://doi.org/10.1155/2020/8829713

[3] Koran Salihi, Khaleel H. Younis, "Rheological Behavior of Self-Compacting Geopolymer Concrete Containing Recycled Aggregates: Effect of $\mathrm{Na}_{2} \mathrm{SiO}_{3} / \mathrm{NaOH}$ and Molarity of NAOH," Key Engineering Materials, vol.872, pp.79-84, 2021. https://doi.org/10.4028/www.scientific.net /KEM.872.79

[4] Hung VV, Seo S-Y, Kim H-W, Lee G-C, "Permeability and Strength of Pervious Concrete According to Aggregate Size and Blocking Material. Sustainability," Sustainability, vol. 13, no. 1, p. 426, 2021. https://doi.org/10.3390/su13010426

[5] “ACI Committee 522 -ACI PRC-522-10 Report on Pervious Concrete," American Concrete Institute (ACI), Reapproved 2011. https://www.concrete.org/store/product detail.aspx?ItemID $=52210 \&$ Format=PROTECTED_PDF $\&$ Language $=$ English $\&$ Units $=$ US_AND_METRIC

[6] Mohammed S., Mohamed B., Ammar Y., "Pervious Concrete: Mix Design, Properties and Applications," RILEM Technical Letters, vol. 1, pp. 109-115, 2016. https://doi.org/10.21809/rilemtechlett.2016.24

[7] Hozan K Yaba, Harith S Naji, Khaleel H Younis, Talib K Ibrahim, "Compressive and flexural strengths of recycled aggregate concrete: Effect of different contents of metakaolin," Materials Today: Proceedings, vol. 45, part 6, pp. 4719-4723, 2021. https://doi.org/10.1016/j.matpr.2021. 01.164

[8] Sai Sindhu K, Suresh Babu T, "Study and Comparison of Mechanical Properties, Durability and Permeability of M15, M20, M25 Grades of Pervious Concrete with Conventional Concrete," International Journal of Applied Research, vol. 1, no. 10, part J, pp. 676-681, 2015. https://www.allresearchj ournal.com/archives/?year $=2015 \&$ vol $=1 \&$ issue $=10 \&$ part $=$ $\mathrm{J} \&$ ArticleId $=820$

[9] Kacha S., "Utilization of waste materials in the production of pervious concrete-A Review," International Journal of Scientific Research and Development, vol. 4, no. 9, pp. 442-449, 2016. http://ijsrd.com/Article.php?manuscript=IJ SRDV4I90290

[10] Khaleel H. Younis, Firas F. Jirjees, Hozan K. Yaba, Shelan M. Maruf, "Experimental Study on Impact Resistance of Concrete Containing Steel Fibers," Key Engineering Materials, vol.872, pp.1-6,
2021.https://doi.org/10.4028/www.scientific.net/KEM.872. 1

[11] "BS EN 12390-2:2009, Testing Fresh Concrete Part 2: Slump test," British Standards Institution, London, UK, 2009. https://shop.bsigroup.com/ProductDetail/?pid $=0000$ 00000030164903

[12] "BS EN 12390-3:2009, Testing Hardened Concrete Part 3: Compressive Strength of Test Specimens," British Standards Institution, London, UK, 2009. https://shop.bsig roup.com/ProductDetail/?pid=000000000030253049

[13] "BS EN 12390-6:2009, Testing Hardened Concrete Part 6: Splitting tensile Strength of Test Specimens," British Standards Institution, London, UK, 2009. https://shop.bsig roup.com/ProductDetail/?pid=000000000030200045

[14] "BS EN 12390-5:2009, Testing Hardened Concrete Part 5: Flexural Strength of Test Specimens," British Standards Institution, London, UK, 2009. https://shop.bsigroup.com/ ProductDetail?pid $=000000000030164909$

[15] "ACI 544.2R-89, Measurement of Properties of Fiber Reinforced Concrete," ACI Committee 544, Am. Concr. Inst. Mater. J., 2009. https://www.concrete.org/store/produ ctdetail.aspx?ItemID $=544289 \&$ Format $=$ DOWNLOAD\&L anguage $=$ English $\&$ Units $=$ US_Units

[16] Abhinav K. Sai, Rao N. Srinivasa, "Investigation on impact resistance of steel fibre reinforced concrete," International Research Journal of Engineering and Technology, vol. 3, no. 7, pp. 954-958, 2016.https://www.academia.edu/34668517 /investigation_on_impact_resistance_of_steel_fibre_reinfo rced_concrete

[17] Diyuan Li, Ali Toghroli, Mahdi Shariati, Fathollah Sajedi, Dieu Tien Bui, Peiman Kianmehr, Edy Tonnizam Mohamad, Majid Khorami, "Application of polymer, silica-fume and crushed rubber in the production of Pervious concrete," Smart Struct. Syst, vol. 23, no. 2, pp. 207-214, 2019. https://doi.org/10.12989/sss.2019.23.2.207

[18] Silva RV, De Brito J, Dhir RK, "Fresh-state performance of recycled aggregate concrete: A review," Construction and Building Materials, vol. 178, pp. 19-31, 2018. https://www.sciencedirect.com/science/article/abs/pii/S095 0061818312248

[19] Ayser J. Ismail, Khaleel H. Younis, Shelan M. Maruf, "Recycled Aggregate Concrete Made with Silica Fume: Experimental Investigation," Civil Engineering and Architecture, vol. 8, no. 5, pp. 1136-1143, 2020. DOI: 10.13189/cea.2020.080540

[20] Khaleel H. Younis, "Metakaolin modified recycled aggregate concrete containing recycled steel fibers," Materials Today: Proceedings, vol. 45, part 6, pp. 4689-4694, 2021. https://doi.o rg/10.1016/j.matpr.2021.01.120

[21] Çakır Ö., "Experimental analysis of properties of recycled coarse aggregate (RCA) concrete with mineral additives," Construction and Building Materials, vol. 68, pp. 17-25, 2014. https://doi.org/10.1016/j.conbuildmat.2014.06.032

[22] Gutiérrez Marta Sánchez de Juan, Pilar Alaejos Gutiérrez "Study on the influence of attached mortar content on the properties of recycled concrete aggregate," Construction and building materials, vol. 23, no. 2, pp. 872-877, 2009. https://doi.org/10.1016/j.conbuildmat.2008.04.012 
[23] Katrina McNeil, Thomas H.-K. Kang, "Recycled concrete aggregates: A review," International journal of concrete structures and materials, vol. 7, no. 1, pp. 61-69, 2013. DOI:10.1007/s40069-013-0032-5
[24] Leon Raj J., Chockalingam T., "Strength and abrasion characteristics of pervious concrete," Road Materials and Pavement Design, vol. 21, no. 8, pp. 2180-2197, 2020. https://doi.org/10.1080/14680629.2019.1596828 